\title{
A novel technique for retrospective genetic analysis of the response to vaccination or infection using cell-free DNA from archived sheep serum and plasma
}

\author{
Eve Hanks ${ }^{1,4^{*}} \mathbb{D}$, Helen Todd ${ }^{2}$, Javier Palarea-Albaladejo ${ }^{3}$, Tom N. McNeilly ${ }^{2}$, Collette Britton ${ }^{1^{*}}$
} and Keith T. Ballingall $2^{*}$

\begin{abstract}
Genetic variation is associated with differences in disease resistance and susceptibility among individuals within a population. To date, molecular genetic analyses of host responses have relied on extraction of genomic DNA from whole blood or tissue samples. However, such samples are not routinely collected during large-scale field studies. We demonstrate that cell-free genomic DNA (cfDNA) may be extracted and amplified from archived plasma samples, allowing retrospective analysis of host genetic diversity. This technique was also applicable to archived serum samples up to 35 years old and to different ruminant species. As proof of concept, we used this cfDNA approach to genotype the major histocompatibility complex (MHC) class II DRB1 locus of 224 Merino sheep which had participated in field trials of a commercial Haemonchus contortus vaccine, Barbervax ${ }^{\circledR}$, in Australia. This identified a total of 51 different DRB1 alleles and their relative frequencies. This is the first study to examine host MHC diversity using DNA extracted from archived plasma samples, an approach that may be applied to retrospective analyses of genetic diversity and responses to vaccination or infection across different species and populations.
\end{abstract}

\section{Introduction}

Previous molecular studies of the influence of genetic diversity on the response to vaccination or infection have relied on the extraction of genomic DNA from blood or tissue samples collected during field trials. In the absence of such material, retrospective analyses are not easily achieved. However recent advances in the field of circulating cell free DNA (cfDNA) as potential biomarkers of

\footnotetext{
*Correspondence: eve.hanks@sac.co.uk; collette.britton@glasgow.ac.uk; keith. ballingall@moredun.ac.uk

${ }^{1}$ Institute of Biodiversity, Animal Health and Comparative Medicine, University of Glasgow, Bearsden Road, Glasgow G61 1QH, UK

${ }^{2}$ Moredun Research Institute, Pentlands Science Park, Penicuik, Edinburgh EH26 OPZ, UK

${ }^{4}$ SAC Consulting: Veterinary Services, SRUC Veterinary Services, Pentland Science Park, Bush Loan, Penicuik, Midlothian EH26 OPZ, UK

Full list of author information is available at the end of the article
}

disease $[1,2]$ led us to examine whether DNA of sufficient quality and quantity could be extracted from archived ovine plasma and serum samples for MHC genotyping. The re-use of material from previous vaccine trials allows implementation of the three Rs; replacement, reduction and refinement and, therefore, satisfies animal welfare and ethical use of animals in science requirements [3]. To demonstrate the utility of the method, we sought to determine whether genomic DNA could be obtained from archived plasma samples, and tested if alleles of the Ovar-MHC class II locus could be amplified from these samples. We focussed on the DRB1 locus which is the most highly polymorphic MHC class II locus of domestic sheep (Ovis aries) $[4,5]$. The MHC class II genes encode dimeric cell surface glycoproteins that present peptides to the adaptive immune system for recognition by CD4+ $\mathrm{T}$ cell receptors $[6,7]$. MHC class II diversity plays an

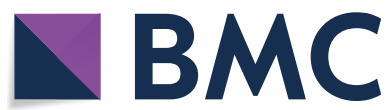

(c) The Author(s) 2020. This article is licensed under a Creative Commons Attribution 4.0 International License, which permits use, sharing, adaptation, distribution and reproduction in any medium or format, as long as you give appropriate credit to the original author(s) and the source, provide a link to the Creative Commons licence, and indicate if changes were made. The images or other third party material in this article are included in the article's Creative Commons licence, unless indicated otherwise in a credit line to the material. If material is not included in the article's Creative Commons licence and your intended use is not permitted by statutory regulation or exceeds the permitted use, you will need to obtain permission directly from the copyright holder. To view a copy of this licence, visit http://creativeco mmons.org/licenses/by/4.0/. The Creative Commons Public Domain Dedication waiver (http://creativecommons.org/publicdomain/ zero/1.0/) applies to the data made available in this article, unless otherwise stated in a credit line to the data. 
important role in determining the type and intensity of the immune response to foreign antigens within a population [4].

Previous studies have identified associations between MHC diversity and resistance or susceptibility to gastrointestinal nematodes (GIN) infection in different sheep breeds [8-12]. MHC influence on the response to GIN vaccination has not been examined. GIN infection is a major clinical and economic problem in humans and livestock and a key constraint to small ruminant productivity globally [13]. Current control relies on administration of anthelmintic drugs, however parasite resistance to the commonly used anthelmintics (benzimidazole, levamisole and avermectin classes) is widespread, with multidrug resistance having considerable impact in some areas [14]. The blood-feeding nematode Haemonchus contortus is the most pathogenic GIN of sheep and goats and the predominant species in warm climates, including large parts of Australia and South America $[15,16]$. Barbervax $^{\circledR}$, the first vaccine commercialised for a GIN of any host, was launched in Australia in 2014 [17] and in South Africa in 2016 [18] after being developed in Scotland, UK. Vaccination is highly effective under controlled challenge conditions $[>70 \%$ reduction in worm burden and $>90 \%$ reduction in faecal egg count (FEC)] [19-21]. However under field challenge during vaccine trials, there was considerable variation between vaccinated individuals in their level of protection, as measured by faecal egg count, blood haemoglobin concentration and anti-Barbervax ${ }^{\circledR}$ antibody titre [22].

In this retrospective analysis, we made use of archived plasma from Australian vaccine field trials to demonstrate the applicability of our novel PCR approach in detailing ovine MHC genotypes. While this study focussed on the MHC class II DRB1 locus, the novel approach we describe using archived serum or plasma is equally applicable to retrospective studies of genetic diversity at other loci and to other infections or vaccinations.

\section{Materials and methods Plasma samples}

Plasma samples were collected during 2011-2013 from Australian Merino sheep during nine Barbervax ${ }^{\circledR}$ registration trials carried out by two companies; CSIRO and VHR, in New South Wales, Australia (Table 1). These studies were designed to test vaccine efficacy. Blood was obtained by jugular venepuncture using sodium heparin tubes and plasma separated at room temperature and stored at $-20{ }^{\circ} \mathrm{C}$. Sheep varied in age from 2 months to 2.5 years and included lambs, yearlings and ewes. The Australian Barbervax ${ }^{\circledR}$ trials obtained ethical approval from the Australian Animal Ethics Committee for each trial and animals were handled in compliance with AEC and any applicable local regulations.

Serum was obtained from Texel cross sheep from a 2014 Barbervax $^{\circledR}$ trial at the Moredun Research Institute (MRI), with ethical approval from MRI Experiments and Ethics Committee (MRI E46 11) and were conducted under approved UK Home Office licence (PPL 60/03899) in accordance with the 1986 Animals (Scientific Procedures) Act. Ovine serum collected between 1984 and 2004 and archived bovine and caprine serum were obtained from MRI archives.

\section{Barbervax ${ }^{\circledR}$ vaccination schedules}

Merino lambs were vaccinated subcutaneously five times during the grazing season over spring and summer, and yearlings and ewes given four doses of vaccine at 3-6 weekly intervals. Blood was sampled from all sheep on vaccination days or at fortnightly intervals for anti-Barbervax $^{\circledR} \mathrm{Ab}$ titre measured by ELISA, as described previously [23]. Sheep were organised by trial location, year and age, as shown in Table 1, and totalled 9 separate trials from 2011 to 2013. In each trial 20-40 animals were vaccinated with Barbervax ${ }^{\circledR}$ from which 224 sheep were genotyped.

\section{Table 1 Details of trials for Australian Merino sheep genotyped for this study}

\begin{tabular}{lllll}
\hline Company & Site & Year of trial & Number of sheep genotyped & Age of sheep \\
\hline CSIRO & Armidale, New South Wales & 2011 & 4 & Lambs \\
CSIRO & Armidale, New South Wales & 2012 & 30 & Lambs \\
CSIRO & New South Wales & 2012 & 27 & Yearlings \\
CSIRO & New South Wales & 2013 & 20 & Ewes \\
VHR & Armidale, New South Wales & 2012 & 36 & Lambs \\
VHR & Dundee, New South Wales & 2012 & 28 & Yearlings \\
VHR & Kingston, New South Wales & 2012 & 25 & Yearlings \\
VHR & Dundee, New South Wales & 2013 & 24 & Ewes \\
VHR & Kingston, New South Wales & 2013 & 30 & Ewes \\
\hline
\end{tabular}




\section{Preparation of genomic DNA}

Genomic DNA (gDNA) was prepared in the UK, from archived plasma samples using the Qiagen DNeasy Blood \& Tissue kit (Qiagen UK, 69504), with the only modification to the standard procedure being the use of serum or plasma instead of blood or tissue. The following was added to a $1.5 \mathrm{~mL}$ Eppendorf tube: $100 \mu \mathrm{L}$ serum or plasma, $100 \mu \mathrm{L}$ PBS, $20 \mu \mathrm{L}$ Proteinase $\mathrm{K}$ and $200 \mu \mathrm{L}$ of buffer AL. The protocol provided with the kit was then followed. Eluted DNA ( $50 \mu \mathrm{L})$ was quantified using Nanodrop spectrophotometry (ThermoFisher Scientific). This indicated a typical concentration of $5-15 \mathrm{ng} / \mu \mathrm{L}$, therefore a yield of $250-750 \mathrm{ng}$ gDNA per $100 \mu \mathrm{L}$ plasma was obtained. There was no obvious difference in yield of gDNA using serum or plasma.

\section{PCR amplification of the ovine MHC class II DRB1 locus} Oligonucleotide PCR primers targeting the $5^{\prime}$ and $3^{\prime}$ intronic regions flanking, or partially overlapping the highly polymorphic second exon of the Ovar-DRB1 gene were utilised. Primers are listed in Table 2 and their locations relative to the second exon of the DRB1 gene are shown diagrammatically in Additional file 1. The primers had previously been designed to amplify $D R B 1$ exon 2 using DNA from whole blood [6], with the exception of nested primers 455 and KBEH1 which were new to this study. Different primer combinations were used in nested or hemi-nested PCR reactions to optimise amplification of the second exon using the DNA isolated from plasma. Primers 275 and 329 were used in the first round PCR then 455 and 329 in the second round or, if no amplification was achieved, an alternative combination of PCR primers, 330 and 329 in the first round and 455 and 329 in the second round were used. The combination of primers 455 and 329 in the first round and primers KBEH1 and 329 in the second round improved the amplification of both alleles in animals initially typed as homozygous and this primer combination was used to validate all homozygous animals.

Nested and hemi-nested PCR was conducted in $50 \mu \mathrm{L}$ reactions consisting of $200 \mathrm{nM}$ of each primer, 1 Unit
OneTaq polymerase (New England BioLabs, M0480S) and corresponding buffer and $2-4 \mu \mathrm{L}(20-40 \mathrm{ng})$ of purified gDNA as template. Two microliters of first round PCR product was used as template in a second round of PCR. First round PCR cycling conditions were: $94{ }^{\circ} \mathrm{C}$ for $2 \mathrm{~min}$, followed by $15-20$ cycles at $94{ }^{\circ} \mathrm{C}$ for $30 \mathrm{~s}$, $58-60{ }^{\circ} \mathrm{C}$ for $30 \mathrm{~s}$, and $72{ }^{\circ} \mathrm{C}$ for $30 \mathrm{~s}$, with a final extension at $72{ }^{\circ} \mathrm{C}$ for $4 \mathrm{~min}$. The second round used the same cycling conditions, but for 30 cycles. PCR products were analysed by electrophoresis on $1 \%$ agarose gels and sent directly for purification and sequencing or sequenced following gel excision and purification using the Wizard SV Gel and PCR Clean-Up System (Promega, A9281). All PCR products were sequenced in both directions by Eurofins Genetic Services (Germany), using terminal primers.

\section{Cloning of Ovar-DRB1 PCR products}

Alleles that proved difficult to annotate from direct sequencing of the PCR product were cloned into the pGEM-T-easy vector (Promega, A1360) and transformed into E. coli JM109 cells, applying blue/white selection with IPTG (isopropyl $\beta$-D-1-thiogalatopyranoside, Merck 367-93-1) and X-gal (5-bromo-4-chloro-3-indolyl $\beta$-Dgalactopyranoside, ThermoFisher Scientific B1690). Twelve colonies per PCR product were PCR screened for the correct insert using primers 455 and 329. Individual clones representing both alleles were identified by digestion of the colony PCR product with $5 \mathrm{U}$ of the frequent cutting restriction enzyme RsaI (ThermoFisher Scientific, ER1121) at $37^{\circ} \mathrm{C}$ for $1 \mathrm{~h}$ [6]. RsaI was inactivated at $80^{\circ} \mathrm{C}$ and digested PCR products $(15 \mu \mathrm{L})$ were separated on an $8 \%$ polyacrylamide gel. DNA from a minimum of three clones representing both alleles, as indicated by the RsaI digest pattern, was sequenced in both directions.

\section{Ovar-DRB1 sequence analysis}

Sequences were analysed using the SeqMan Pro 14 program within the DNASTAR software package. Contigs were assembled from the forward and reverse DNA sequences from each plasma sample. Heterozygous

Table 2 Oligonucleotide primers used for amplification of the second exon of the Ovar-DRB1 locus. Adapted from [6]

\begin{tabular}{llll}
\hline Primer name & $\begin{array}{l}\text { Position relative to the first base of the second } \\
\text { exon of the Ovar-DRB1 locus }\end{array}$ & Forward (F) or reverse (R) & Sequence \\
\hline 275 & Intron $1(-55$ to -35$)$ & $\mathrm{F}$ & ATTAGCCTCTCCCCAGGAGTC \\
329 & Exon 2/intron 2 $(263$ to +15$)$ & $\mathrm{R}$ & CACCCCCGCGCTCAC/CTCGCCGC \\
330 & Intron 1 $(-55$ to -35$)$ & $\mathrm{F}$ & ATTAGCCTCYCCCCAGGAGKC \\
455 & Intron 1/exon 2 $(-16$ to +8$)$ & $\mathrm{F}$ & TATCCCGTCTCTGCAG/CACATTTC \\
KBEH1 & Intron 1/exon 2 $(-7$ to +14$)$ & $\mathrm{F}$ & TCTGCAG/CACATTTCYTGGAG
\end{tabular}

Intron 1 sequence is indicated as negative, intron 2 sequence is indicated as positive. Positions 1 to 270 indicate exon 2 . The intron exon boundary is marked by /. 
positions were manually labelled according to the International Union of Biochemistry (IUB) ambiguity code (Nomenclature Committee of the International Union of Biochemistry, 1984). Each sequence was searched against a database of all known Ovar-DRB1 alleles downloaded from the immunopolymorphism database (IPD)-MHC database $[5,7,24]$ using a Basic Local Alignment Search Tool (BLAST). The two alleles providing the highest alignment scores were then manually checked to ensure a perfect match.

\section{Results}

\section{Amplification of MHC class II DRB1 alleles from archived} plasma from Merino sheep

The second exon of the ovine MHC class II DRB1 locus was successfully amplified by hemi-nested PCR from DNA template extracted from archived plasma samples from Merino sheep. The samples had been collected during 2011-2013 Australian Barbervax field trials and stored at $-20{ }^{\circ} \mathrm{C}$ prior to DNA extraction. From a total of 257 samples initially tested by PCR, products were obtained from 224 Merino samples (87\%). This demonstrated that DNA of sufficient quantity and quality can be extracted from most archived plasma samples for amplification of the DRB1 locus.

\section{Sequence analysis of ovine DRB1 alleles}

Two hundred and twenty-four DNA samples provided sequence of a quality that allowed identification of one or both alleles directly from the PCR product. Within this, thirty-two sequences obtained from these 224 samples $(7 \%)$ were of insufficient quality to determine allele type directly. This was resolved by cloning the PCR products from these samples into the pGEM-T-Easy vector and sequencing the cloned products (see "Materials and methods").

All alleles identified in this study were present within the IPD-MHC Database [24]. In total, 51 alleles were identified. Of the 224 sheep genotyped at the DRB1 locus, 14 (frequency of 0.063 ) were homozygous. This value is similar to previous reports across a range of sheep breeds (0.075) [6]. The 7 most frequently occurring alleles are listed in Table 3 and the remaining 44 alleles identified and their frequencies are shown in Additional file 2.

\section{Application to other breeds, species and samples of different ages}

Additionally, sera from seven Texel cross sheep, from a 2014 Barbervax $^{\circledR}$ trial at the Moredun Research Institute (MRI), UK, were PCR amplified and sequenced. This demonstrated that the technique can be applied across different breeds (representative PCR data shown in Additional file 3). To test application of the approach to older
Table 3 Relative frequency of the seven most abundant Ovar-DRB1 alleles in Merino sheep

\begin{tabular}{lll}
\hline Allele name & Total & $\begin{array}{l}\text { Relative } \\
\text { frequency }\end{array}$ \\
\hline $04: 01$ & 21 & 0.050 \\
$07: 01$ & 37 & 0.088 \\
$08: 03$ & 48 & 0.114 \\
$15: 02$ & 46 & 0.109 \\
$17: 02$ & 20 & 0.048 \\
$19: 02$ & 28 & 0.067 \\
$20: 02$ & 29 & 0.069 \\
\hline
\end{tabular}

samples and to different species, we also included three ovine serum samples from the MRI archive from 1984, three from 1994 and three from 2004. In addition, we tested amplification using three bovine and three caprine serum samples provided by the Virus Surveillance Unit at MRI. All samples produced PCR products of the expected size.

\section{Discussion}

MHC genotype can impact on host responses to parasitic disease by influencing the range of antigenic peptides presented for recognition by the adaptive immune system. Numerous studies have shown the relevance of MHC diversity on resistance or susceptibility to infection with nematode parasites in many species including mice [25, 26], sheep [8-12] and cattle [27]. However, MHC genotyping has relied on the availability of cell or tissue samples for DNA extraction. Here we report for the first time that plasma or serum may be employed as an appropriate source of genomic DNA for sequence based analysis of MHC allelic diversity. Our high success rate of amplification and sequencing shows that the yield and quality of DNA obtained from archived plasma or serum samples is sufficient for detailed, retrospective analysis of MHC diversity in population based studies. Using this approach we were able to genotype the MHC DRB1 locus of 224 sheep and differentiate between homozygous and heterozygous animals. The method we developed is relevant to future monitoring of genetic influences on vaccine efficacy, disease susceptibility and to selective breeding. Additionally, it opens up the opportunity to include targeted DNA sequence analysis retrospectively to studies that have relied on phenotypic data alone. The approach is also amenable to high throughout sequencing of pooled amplicons from of large numbers of samples using molecular barcodes incorporated into each primer.

The source of DNA present in the serum or plasma samples is currently unknown. It seems unlikely to be 
derived from lysed white blood cells as the samples showed no evidence of cell lysis and the amount of DNA extracted was consistent across all samples. The most likely source is cfDNA. cfDNA was first discovered in 1948 in human plasma [28] and is now known to be released by a variety of cells into the circulation [29]. It has been shown that tissue damage such as cardiomyocyte death [30], inflammatory processes such as venous thromboembolism [31] and potentially parasitic infections [32], may all be characterised by detection of cfDNA. This technique is non-invasive, apart from the initial blood sampling, and the use of cfDNA for biomarker discovery is rapidly increasing, particularly for diagnosis, monitoring and prognosis of specific cancers; a "liquid biopsy" [33]. Furthermore, cfDNA may be biologically active and has been shown to have immunoregulatory effects in macrophages in vitro [34].

Here, to demonstrate application of the technique, we focused on amplification of the highly polymorphic second exon of the MHC class II DRB1 gene in sheep, the major region encoding the peptide-antigen binding site [35]. However, this approach is equally applicable to other loci that may influence or be used as markers of response to vaccination or infection. Having established the technique, it will be important to determine its wider applicability to disease monitoring, diagnostics and selective breeding. We successfully amplified and sequenced the DRB1 locus from $87 \%(224 / 257)$ of plasma samples from Australian field trials of the Barbervax $^{\circledR}$ vaccine. No novel DRB1 alleles were identified, which is both a testament to the comprehensive nature of the IPD-MHC database and the reliability of the approach. Contamination is a potential pitfall associated with all PCR amplification techniques. We had no evidence of contamination and no disparity in the number of homozygous animals in comparison to similar studies using DNA extracted from whole blood ("Sequence analysis of ovine DRB1 alleles" section) and no evidence that one or two alleles dominated the findings.

Optimisation of the PCR procedure by employing different combinations of primers allowed reliable identification of animals homozygous or heterozygous at the $D R B 1$ locus. Homozygosity was represented by only a small number of sheep (14). Current theory suggests that the evolution and maintenance of MHC diversity is likely to be driven by interaction with rapidly evolving pathogens and that heterozygosity offers some advantage in protection against infection [10,36, 37]. It is worth noting that homozygosity at the $D R B 1$ locus does not mean that the animal is always homozygous across the MHC class II region. The ovine MHC class II region includes a range of polymorphic $D Q$ loci [38] and a number of studies have identified diversity at the duplicated $D Q A$ and $D Q B$ loci linked with identical $D R B 1$ alleles [4].

A total of 224 Merino sheep were successfully genotyped at the DRB1 locus. Fifty-one alleles were identified at relative frequencies ranging from 0.114 to 0.002 ; the level of heterozygosity supports the concept that all available alleles were amplified. The same PCR primer combinations amplified $D R B 1$ from DNA isolated from the serum of Texel cross sheep and from bovine and caprine serum, demonstrating the wide applicability of the technique, although primer optimisation may be required for each species. In previous studies, the primer combinations employed in this study successfully amplified $D R B 1$ from genomic DNA obtained from whole blood samples from a range of sheep breeds [6] and from goats $[39,40]$. In this study, amplification of the Ovar-DRB1 locus failed in 33 samples. This is most likely due to degradation of the DNA following storage and freeze/thaw cycles rather than a failure to amplify certain alleles.

No specific $D R B 1$ alleles have previously been associated with resistance to $H$. contortus infection although microsatellite [10] and single nucleotide polymorphisms within Ovar-DRB1 have been identified in resistant and susceptible sheep from St. Croix, Katahdin and Dorper breeds [12]. One DRB1 allele (11:01) has been associated in Suffolk sheep with lower worm burdens and higher mast cell and plasma platelet counts following infection with the GIN Teladorsagia circumcincta [36] and with reduced faecal egg count in Texel breed sheep [41]. In future vaccine studies, where more comprehensive information is available, such as animal pedigree, formal statistical generalised linear mixed modelling (GLMM) may be applied to determine any associations between MHC genotype and vaccine efficacy, to better understand host protective responses to vaccination and infection.

In summary, this is the first report of DNA extraction and amplification from plasma or sera for retrospective use in genetic analysis of the outcome of a vaccine field trial. Moreover, we routinely extracted good quality DNA from samples stored for many years, demonstrating a new route to accessing genetic information from archived samples that can be widely applied to examine the effects of MHC and other genes on the outcome of parasitic infections. While this study focussed on the MHC class II $D R B 1$ locus, the approach is equally applicable to retrospective studies of genetic diversity at other loci.

\section{Supplementary information}

Supplementary information accompanies this paper at https://doi. org/10.1186/s13567-020-0737-9.

Additional file 1. Diagram of Ovar-DRB1 Exon 2 region showing the position of each primer used in PCR genotyping. 


\section{Additional file 2. Low frequency Ovar-DRB1 alleles sequenced from Merino sheep.}

Additional file 3. Specific PCR amplification of Ovar-DRB-1 exon 2 using hemi-nested PCR. Agarose gel electrophoresis of PCR products of DNA from plasma of seven Merinos lambs (1-7). Negative control PCR ( $N$, no template DNA) showed no amplified product. Mr indicates $100 \mathrm{bp}$ DNA ladder.

\section{Abbreviations}

MHC: major histocompatibility complex; GIN: gastrointestinal nematode; cfDNA: cell-free DNA; gDNA: genomic DNA; IPD: immunopolymorphism database; BLAST: Basic Local Alignment Search Tool.

\section{Acknowledgements}

Funders: Moredun Foundation and University of Glasgow Industrial Partnership Ph.D. studentship. TNM, HT, KTB, JPA are supported by the Scottish Government's Rural and Environment Science and Analytical Services (RESAS) Strategic Research Programme 2016-2021. The authors thank W. David Smith and George F Newlands for helpful discussions during the preparation of this manuscript, access to plasma samples and data associated with the Australian Barbervax ${ }^{\circledR}$ field trials, and thank Adam Hayward for comments on the manuscript. The Barberva $x^{\circledR}$ trials from which plasma samples were obtained were funded by Meat and Livestock Australia (MLA) and the authors acknowledge the assistance of CSIRO and VHR in the sample collection.

\section{Authors' contributions}

EH, KTB and CB designed the experiments. EH performed the experiments with $\mathrm{HT}$ in an advisory role. JP-A and TNMCN contributed to data analysis and writing of the manuscript. All authors read and approved the final manuscript.

\section{Competing interests}

The authors declare that they have no competing interests.

\section{Author details}

${ }^{1}$ Institute of Biodiversity, Animal Health and Comparative Medicine, University of Glasgow, Bearsden Road, Glasgow G61 1QH, UK. ${ }^{2}$ Moredun Research Institute, Pentlands Science Park, Penicuik, Edinburgh EH26 OPZ, UK. ${ }^{3}$ Biomathematics and Statistics Scotland, JCMB, The King's Buildings, Peter Guthrie Tait Road, Edinburgh EH9 3FD, UK. ${ }^{4}$ SAC Consulting: Veterinary Services, SRUC Veterinary Services, Pentland Science Park, Bush Loan, Penicuik, Midlothian $\mathrm{EH} 26 \mathrm{OPZ}$, UK.

Received: 2 December 2019 Accepted: 16 January 2020

Published online: 05 February 2020

\section{References}

1. Khetrapal P, Lee MWL, Tan WS, Dong L, de Winter P, Feber A, Kelly JD (2018) The role of circulating tumour cells and nucleic acids in blood for the detection of bladder cancer: a systematic review. Cancer Treat Rev 66:56-63

2. Pös O, Biró O, Szemes T, Nagy B (2018) Circulating cell-free nucleic acids: characteristics and applications. Eur J Hum Genet 26:937-945

3. National Centre for the Replacement Refinement \& Reduction of Animals in Research. https://www.nc3rs.org.uk/the-3rs. Accessed 20 Sept 2019

4. Atlija M, Gutierrez-Gil B, Arranz JJ, Semmer J, Stear MJ, Buitkamp J (2015) Major histocompatibility complex class IIB polymorphism in an ancient Spanish breed. Immunogenetics 67:531-537

5. Ballingall KT, Herrmann-Hoesing L, Robinson J, Marsh SGE, Stear MJ (2011) A single nomenclature and associated database for alleles at the major histocompatibility complex class II DRB1 locus. Tissue Antigens 77:546-553

6. Ballingall KT, Tassi R (2010) Sequence-based genotyping of the sheep MHC class II DRB1 locus. Immunogenetics 62:31-39

7. Maccari G, Robinson J, Ballingall K, Guethlein LA, Grimholt U, Kaufman J, Ho C-S, de Groot NG, Flicek P, Bontrop RE, Hammond JA, Marsh SGE (2017) IPD-MHC 2.0: an improved inter-species database for the study of the major histocompatibility complex. Nucleic Acids Res 45:D860-D864
8. Schwaiger FW, Gostomski D, Stear M, Duncan JL, McKellar QA, Epplen JT, Buitkamp J (1995) An ovine major histocompatibility complex DRB1 allele is associated with low faecal egg count following natural, predominantly Ostertagia circumcincta infection. Int J Parasitol 25:815-822

9. Paterson S, Wilson K, Pemberton JM (1998) Major histocompatibility complex variation associated with juvenile survival and parasite resistance in a large unmanaged ungulate population (Ovis aries L.). Proc Natl Acad Sci U S A 95:3714-3719

10. Castillo JA, Medina RD, Villalobos JM, Gayosso-Vazquez A, Ulloa-Arvizu R, Rodriguez RA, Ramirez HP, Morales RA (2011) Association between major histocompatibility complex microsatellites, fecal egg count, blood packed cell volume and blood eosinophilia in Pelibuey sheep infected with Haemonchus contortus. Vet Parasitol 177:339-344

11. Valilou RH, Rafat SA, Notter DR, Shojda D, Moghaddam G, Nematollahi A (2015) Fecal egg counts for gastrointestinal nematodes are associated with a polymorphism in the MHC-DRB1 gene in the Iranian Ghezel sheep breed. Front Genet 6:105

12. Estrada-Reyes ZM, Tsukahara Y, Goetsch AL, Gipson TA, Sahlu T, Puchala T, Wang Z, Hart SP, Mateescu RG (2018) Effect of Ovar-DRA and Ovar-DRB1 genotype in small ruminants with haemonchosis. Parasite Immunol 40:e12534

13. Rist CL, Garchitorena A, Ngonghala CN, Gillespie TR, Bonds MH (2015) The burden of livestock parasites on the poor. Trends Parasitol 31:527-530

14. Kaplan RM, Vidyashankar AN (2012) An inconvenient truth: global worming and anthelmintic resistance. Vet Parasitol 186:70-78

15. Emery DL, Hunt PW, Le Jambre LF (2016) Haemonchus contortus: the then and now, and where to from here? Int J Parasitol 46:755-769

16. Amarante AFT (2014) Sustainable worm control practices in South America. Small Ruminant Res 118:56-62

17. The Australian Barbervax ${ }^{\circledR}$ website. www.barbervax.com.au. Accessed 7 Jan 2018

18. The South African Barbervax ${ }^{\circledR}$ website. https://vet360.vetlink.co.za/cpdwirevax-vaccination-haemonchus-contortus-sheep/. Accessed 1 Dec 2018

19. Munn EA, Smith TS, Smith H, James FM, Smith FC, Andrews SJ (1997) Vaccination against Haemonchus contortus with denatured forms of the protective antigen $\mathrm{H} 1$ 1. Parasite Immunol 19:243-248

20. Newton SE, Munn EA (1999) The development of vaccines against gastrointestinal nematode parasites, particularly Haemonchus contortus. Parasitol Today 15:116-122

21. Roberts B, Antonopoulos A, Haslam SM, Dicker AJ, McNeilly TN, Johnston SL, Dell A, Knox DP, Britton C (2013) Novel expression of Haemonchus contortus vaccine candidate aminopeptidase $\mathrm{H} 11$ using the free-living nematode Caenorhabditis elegans. Vet Res 44:111

22. The Meat and Livestock Australia website. https://www.mla.com.au/ research-and-development/search-rd-reports/final-report-details/Anima I-Health-and-Biosecurity/A-commercial-vaccine-for-Barbers-pole-wormfurther-development/171. Accessed 3 Apr 2018

23. Salle G, Laing R, Cotton JA, Maitland K, Martinelli A, Holroyd N, Tracey A, Berriman M, Smith WD, Newlands GFJ, Hanks E, Devaney E, Britton C (2018) Transciptomic profiling of nematode parasites surviving vaccine exposure. Int J Parasitol 48:395-402

24. The (IPD)-MHC database. www.ebi.ac.uk/ipd/mhc/group/OLA/. Accessed 8 Jan 2018

25. Meyer-Lucht Y, Sommer S (2005) MHC diversity and the association to nematode parasitism in the yellow-necked mouse (Apodemus flavicollis). Mol Ecol 14:2233-2243

26. Rodrigues RM, Silva NM, Gonçalves AL, Cardoso CR, Alves R, Gonçalves FA, Beletti ME, Ueta MT, Silva JS, Costa-Cruz JM (2009) Major histocompatibility complex (MHC) class II but not MHC class I molecules are required for efficient control of Strongyloides venezuelensis infection in mice. Immunology 128:e432-e441

27. Stear MJ, Hetzel DJ, Brown SC, Gershwin LJ, Mackinnon MJ, Nicholas FW (1990) The relationships among ecto- and endoparasite levels, class I antigens of the bovine major histocompatibility system, immunoglobulin E levels and weight gain. Vet Parasitol 34:303-321

28. Mandel $P$, Metais $P$ (1948) Les acides nucléiques du plasma sanguine chez I'homme. C R Seances Soc Biol Fil 142:241-243 (in French)

29. Stewart CM, Tsui DWY (2018) Circulating cell-free DNA for non-invasive cancer management. Cancer Genet 228-229:169-179 
30. Zemmour H, Planer D, Magenheim J, Moss J, Neiman D, Gilon D, Korach A, Glaser B, Shemer R, Landesberg G, Dor Y (2018) Non-invasive detection of human cardiomyocyte death using methylation patterns of circulating DNA. Nat Commun 9:1443

31. Jimènez-Alcázar $M$, Limacher $A$, Panda R, Méan $M$, Bitterling J, Peine $S$, Renné T, Beer JH, Aujesky D, Lämmie B, Fuchs TA (2018) Circulating extracellular DNA is an independent predictor of mortality in elderly patients with venous thromboembolism. PLoS ONE 13:e0191150

32. Baraquin A, Hervouet $E$, Richou C, Flori P, Peixoto P, Azizi A, Delabrousse E, Blagosklonov O, Umhang G, Bresson-Hadni S, Valot B, Grenouillet F (2018) Circulating cell-free DNA in patients with alveolar echinococcosis. Mol Biochem Parasitol 222:14-20

33. Huang YF, Chen YJ, Fan TC, Chang NC, Chen YJ, Midha MK, Chen TH, Yang HH, Wang YT, Yu AL, Chiu KP (2018) Analysis of microbial sequences in plasma cell free DNA for early-onset breast cancer patients and healthy females. BMC Med Genom 13:16

34. Waldrogel Abramowski S, Tirefort D, Lau P, Guichebaron A, Taleb S, Modoux C, Lemoine Chaduc C, Bruyere Cerdan P, Roux Lombard P, Lecompte T, Preynat-Seauve O (2018) Cell-free nucleic acids are present in blood products and regulate genes of innate immune response. Transfusion 58:1671-1681

35. Ohta T (1998) On the pattern of polymorphisms at major histocompatibility complex loci. J Mol Evol 46:633-638

36. Hassan M, Good B, Hanrahan JP, Campion D, Sayers G, Mulcahy G, Sweeney T (2011) The dynamic influence of the DRB1*1101 allele on the resistance of sheep to experimental Teladorsagia circumcincta infection. Vet Res 42:46
37. Geldhof P, Newlands GF, Nyame K, Cummings R, Smith WD, Knox DP (2005) Presence of the LDNF glycan on the host-protective H-gal-GP fraction from Haemonchus contortus. Parasite Immunol 27:55-60

38. Ballingall KT, Lantier I, Todd H, Lantier F, Rocchi M (2018) Structural and functional diversity arising from intra- and inter- haplotype combinations of duplicated DQA and B loci within the ovine MHC. Immunogenetics 70:257-269

39. Shrivastava K, Kumar P, Sahoo NR, Kumar A, Khan MF, Kumar A, Prasad A, Patel BHM, Nasir A, Bhushan B, Sharma D (2015) Genotyping of major histocompatibility complex Class II DRB gene in Rohilkandi goats by polymerase chain reaction-restriction fragment length polymorphism and DNA sequencing. Vet World 8:1183-1188

40. Ballingall KT, Todd H (2019) An official nomenclature of major histocompatibility complex allele sequences from the domestic goat (Capra hircus). HLA 93:36-38

41. Alsagher OAA, Murphy L, Stear A, Fairlie-Clarke K, Brujeni GN, DonskawŁysoniewska K, Groth D, Buitkamp J, Stear MJ (2019) Association of MHC class II haplotypes with reduced faecal nematode egg count and IgA activity in British Texel sheep. Parasite Immunol 41:e12626

\section{Publisher's Note}

Springer Nature remains neutral with regard to jurisdictional claims in published maps and institutional affiliations.
Ready to submit your research? Choose BMC and benefit from:

- fast, convenient online submission

- thorough peer review by experienced researchers in your field

- rapid publication on acceptance

- support for research data, including large and complex data types

- gold Open Access which fosters wider collaboration and increased citations

- maximum visibility for your research: over $100 \mathrm{M}$ website views per year

At BMC, research is always in progress.

Learn more biomedcentral.com/submissions 